\title{
The Study of Local Government Civil Servants Construction Based on Perspective Administrative Culture
}

\author{
Zhou YongHua ${ }^{1}$ Tang Xianbin ${ }^{2}$ \\ ${ }^{1}$ College of Politics and Public Management,Xinjiang University,Urumqi Xinjiang,China. \\ Email: xjdxzyh@163.com \\ ${ }^{2}$ College of Politics and Public Management,Xinjiang University,Urumqi Xinjiang,China. \\ Email:1002280907@qq.com)
}

\begin{abstract}
This paper, based on the relevant research, mainly explains the interaction and mutual influence between administrative culture and government human resource development; clearly presents the homologous symbiosis among the administrative culture and human resource development of government. It also puts forward to the arguments that government human resources development should accomplish harmonious development with the administrative environment construction and constant improvement of the administrative culture patterns and human resource development models is required for the purpose of promoting the coordination and interaction between administrative culture and government human resources development.
\end{abstract}

Keywords: Administrative culture; government human resources development; bidirectional interaction

\section{Introduction}

As the criterion and values of administrative organization, the administrative culture can not only preserve the effection and status of human resources in government, and maximize the potential of administrative staff by cultivating the vivid characteristic culture which adapt to the environment of the administrative organization. And on this basis, it has formed the cohesion of the whole organization to contribute to the sound development of government's human resources development. The values and criterio of human recourse which are generated in a specific cultural context will selecte the specific modes, which react on the whole process of conducts. They affect each other.

\section{2. the theoretical basis of bidirectional interaction between administrative culture and government human resource development}

\subsection{The commonality of values}

The value of government human resource of contemporary times is people-focused, while the administrative cultures create a favourable practical environment for administrative staff in order to create common ideas and values on the government human resources. With the requirements of social development, administrative cultures and government human resources, on the basis of public spirit, generally begin to focus on the public benefits and social responsibility, within which the concepts of law, market and information technology started to become more integrated.

\subsection{The commonality of the object}

The government human resource development, taking people's value as its fundamental orientation, focuses on mutural interaction between people and their environment. Administrative culture also focuses on people and people-oriented and how to foster innovative administrative culture, which in turn begins with the study of the bidirectional interaction between people, people and organizations and people and work.

\subsection{The commonality of responsibility goals}

Promoting the culture of administrative organization is a main task of government human resources development and management and a measure to improve the efficiency of government human resources development and administrative culture is also one of the means of construction and development. Administrative culture and the 
government human resource development are all people-focused, which become the maximum force of government human resources to contribute to the construction of service-oriented government.

\subsection{The commonality of functions}

Administrative culture bears the functions of constraints and incentive, which are also the main functions of government human resources development. The government human resource development and management has run the functions of coordination, direction, incentive and radiation through all circles, at the same time government can further enhance the administrative culture's functions by the organizational performance and operational optimization of the executive staff.

\section{Analysis on bidirectional interaction between the administrative culture and the government human resource development.}

This paper made a sampling questionnaire among 500 Xinjiang administrative units on the relationship between the administrative culture and the government human resource development, __ of which are valid. Combined with the questionnaire, typical case studies were made to explore the nature of the study and add its practical significance.

3.1. The administrative culture is conducive to government to establish a scientific human resources administrative value

With the deepening of China's administrative management system reform, innovation, rule of law and inclusiveness have become the top priorities in the construction of administrative culture. Administrative culture helps to overcome individual psychological barriers and eliminate fatigue and other unhealthy moods in the administrative activities; it also helps to establish the correct administrative values and enhance resistance to abuse of power and money, corruption and foster the healthy and scientific values and minds for the government human resources administration.

In the questionnaire, there is an item, namely "Your unit holds a comprehensive review on multiple responsibilities in the administrative process, abandoning the single pursuit for efficiency", $36.7 \%$ of respondents answered "very good", $39.5 \%$ of respondents answered "quite good", $21.1 \%$ of respondents answered "ok", which reflects that the value orientation of the members in these administrative organizations tend to be compatible with that advocated by our country. In the item: "Your administrative value is to serve people, and there is not any alienation about the value", $25.9 \%$ of respondents answered "very good", $46.9 \%$ respondents answered "quite good", no one answered "no", which indicates that the surveyed administrative units are able to take public benefits as their values, serving people wholeheartedly.

\subsection{The administrative culture is conducive to the optimization of administrative acts of government human resources .}

The innovation and change of administrative staff's way of thinking, values and patterns of behaviour are the key factors in the success of administrative reform. In the item: "administrative acts of your unit are all executed by law", $44.9 \%$ of the respondents answered "very good", 35.4\% of respondents answered "quite good", only $2.7 \%$ of the respondents believe "bad".

In the item:"Your behaviour is conducted in accordance with the administrative procedures ", those who think "very good" and "quite good" account for $76.5 \%$ of the total respondents. This shows the administrative culture of these units helps to constrain the behaviours of their administrative staff, who can conduct their administrative action in accordance with the requirements of administrative culture. In the item:"Yourunit emphasizes on the efficiency, control and well-organized operation", $28.6 \%$ of respondents answered "very good", $42.9 \%$ of respondents answered "quite good ", no respondents believe "bad". In the item: " All staff of your unit would like to behave themselves with high standards, and expect high performance", $27.8 \%$ of the respondents answered "very good", $42.9 \%$ of the respondents answered "quite good ", only $0.7 \%$ of the respondents answered "bad", which show that these administrative units pay much attention to efficiency and the staff can behave themselves with high standards.

\subsection{The administrative culture is conducive to scientific decision-making in government human resources.}

Under the background of social transformation, the administrative culture changed the way of 
decision-making in government human resources from pure "project-based" to "comprehensive" thinking; a new way of thinking is developed based on humanism and scientific development, that is taking public benefits for priority, truly representing people's fundamental benefits. Moreover, the administrative culture advocates public benefits first and democratic participation in decision making in the trend of leading subjects' multiple benefits in the social decision-making, which improve the government's "regulation" capabilities and level of scientific decision-making.

In the item: "your organization can and is willing to seek and accept any suggestions on reform", $15 \%$ of respondents answered "very good", $51 \%$ of respondents answered "quite good" and only $2.7 \%$ of respondents answered "bad", which reflect the government's administrative decisions are made under the guidance of democratic and efficient administrative culture .

\subsection{Administrative culture is conducive to enhance the quality of human resources of the government.}

Human resources development and management of the government is a key factor to improve the level of scientific administrative management. The recruitment, training, assessment and performance of the government's human resource development are subject to administrative culture's direct or indirect constraints. In the item: "Your unit organize some activities for staff training for the purpose of improving their quality", $19.7 \%$ of respondents believe that these activities are"very good", while $44.2 \%$ of respondents believe they are "quite good" and only $1.4 \%$ of respondents think they are "bad", which indicate that these units surneyed are focusing on improving staff's overall quality and establishing the learning organization and learning-oriented administrative culture.

3.5. The deviation of the concepts in the spiritual level of administrative culture affects values of government human resources.

In the process of China's transformation from planned economy to market economy, there are a considerable number of administrative officials of different degrees who hold unrealistic fantasy, ignoring people's wishes and feelings, and are absolutely obedient to the higher-level, which clearly show the ideas of "official standard, "" patriarchal leadership". In the investigation in violation of Xinjiang government discipline from January 2006 to March 2009, 3769 people are committed punishment from party and government; 3540 violation cases have been investigated, including 195 cadres at the county level and 15 cadres at regional level; 135 people were transferred to judicial units for trial, serving as a warning for those intend to take corruption.

3.6. The misconducts in the practical level of administrative culture affect the efficiency of government administrative human resources.

In the transitional period, balance is broken between the government's capability and administrative environment in the traditional society. Under this background, heterogeneous sub-culture and popular culture appear. Perhaps popular culture and sub-culture are not in conflict with modern social cultures, but it is worth noting: the negative administrative sub-culture and popular culture may have a negative impact on mainstream culture. For example, a 50000-yuan electric massage chair was granted to the staff of a district court in Urumqi as welfare. If the administrative sub-culture and popular culture are prevalent in local government, this will have a negative impact on the image of the government and administrative efficiency of government human resources as well.

3.7. The government human resources development is conducive to the concept innovation of administrative culture

Innovation of administrative culture is a long-term project, which requires the environment and atmosphere adaptable with the culture. And the government human resources, as the core of administrative organization, need to update the concept of government to regulate the administrative and cultural development, and to promote the concept innovation of administrative. In the item: "The leaders of your organization have the spirit of enterprise management, focusing on performance and administrative innovation"; $19.7 \%$ of respondents answered "very good"; $44.2 \%$ of respondents answered "quite good." In the item: "Your unit pays attention to competition, requiring staff with the quality of innovation and development", $18.4 \%$ of those surveyed answered "very good"; $38.8 \%$ of 
respondents answered "quite good"; $34 \%$ of respondents answered "ok", which indicate that the staff of these units have a sense of administrative cultural innovation, paying attention to performance and competition with the entrepreneurial spirit.

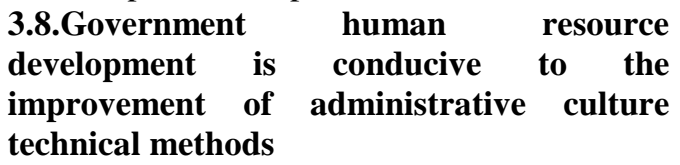

Administrative culture, as a major inherent and humanity way to develop human resources, has been an "invisible rules" in the consciousness of human resources of the government by the inculcation of public spirit and administrative values to the human resources to form a common value and way of thinking within an organizations. For example, on February 10, 2011, Xinjiang Hami Prefecture decided to enforce ten bans to give strict punishment to those administrative staff who have some misconducts such as neglecting, being perfunctory, buck-passing and so on in their work. By doing this, the "barriers" on the way to a smooth passage of public service will be got rid of and government working efficiency will be improved.

\subsection{Government human resource development is conducive to the improvement of soft power in the administrative culture.}

Culture is fundamentally human, cultural competitiveness is essentially the competition of people's cultural quality. Enhancing the cultural soft power is based on improving people's quality. Only by continuously improving people's moral and scientific and cultural qualities, can people's ideals and beliefs be built up and nation's cohesion, solidarity and creativity be formed and enhanced. Good government human resources development helps to strengthen the cultural consciousness of administrative culture, thus improving the administrative culture "soft" power.

3.10. The diversified values among government human resources will lead to" culture-lag " effect in administrative culture.

Culture-lag refers to the time lag between the non-material culture and material culture in the change speed. After Chinese reform and opening up, the full development of Chinese society made it an unstoppable trend for diversified values, which the administrative subjects are caught in the contradictions and confusion during the administrative excution. In February 2010, Xinjiang 41 district-level units have been revoked of the title of honorary civilization, because the leaders' values in these administrative units are biased from those that are advocated by the mainstream administrative values, which had a negative impact on our society and human resources and led to the confusion of values among government human resources and the dislocation with leading values. As a result, administrative subjects will lose their beliefs , overexpand their personal desires and weaken their sense of public service.

3.11. The burnout in work among government human resources may result in "domino" effect in administrative cultures

It is showed in the "working burnout index" survey that: $54.88 \%$ of civil servants have experience working burnout. They are faced with much pressure from buying house, work load, society misunderstanding and career development, of which the most significant is from work load, and government administration work has become a profession with large number of staff suffering from professional burnout. However, while civil servants are lack of social support, and $18 \%$ of them choose to relieve their depression by themselves; while $78 \%$ of civil servants expressed that they would not turn to mental health services treatment for help, only $8 \%$ of people choose to go to doctor.

3.12. The anomie of behavior among government human resources may lead to the distortion in administrative cultural values.

In the process of social transformation, it is very likely that there is less ethical control and constraints for the behaviours of the government human resource. As a result, the anomie of behaviour occur among government human resources. Less control means more choices provided for the administrative staff in the pursuit of personal benefits, which will possibly change their mainstream administrative values such as serving people wholeheartedly, public benefits first, pursuit for truth. For example, "7 •11" Accident happened in Shenlong company, Fukang City. This gas explosion under a coal 
mine caused 83 people died and direct economic loss of 35.17 million yuan. A director from Xinjiang Transportation Bureau misappropriated 70 million yuan transport facilities construction fund, causing direct economic losses of more than 50 million yuan. When the anomie of behaviour happens among government human, they can not select the correct value of the direction, in particular, they can not control their behavior by public ethical norms within the scope allowed by the public ethics, and administrative culture have no control and constraints for their behaviors, resulting in distortion of values in administrative culture.

\section{The path selection for the promotion of bidirectional interaction between administrative culture and government human resource development}

\subsection{The attention should be paid to the homologous symbiotic between administrative culture and government human resource development}

The contents, forms and directions of administrative culture and human resource development and management are determined and restricted by the objective principles and basic requirements of development of social productivity, which also determine people's general cognitive level for administrative environment and managing level of administrative organization. Meanwhile, the level of administrative practice is always associated with cultural activities and management activities. The development of administrative practice changes the objects of administrative culture and government human resource management and consequently leads to the developmentof culture and management.

4.2. Attention should be paid to the harmonious development between government human resources development and administration environment.

Free competition, people-oriented, pursuit for effectiveness and efficiency are the main concepts of contemporary market economy. Therefore the development of administrative culture should emphasize on customer-oriented, market choice and competition, authorization, innovation and reform, and introduce some business strategies like cost, effectiveness, quality, customer satisfaction to administrative culture, building up the concepts of public being focused and citizens being supreme. While government human resources development should adapt to the changes happened in administrative organizational culture so as to bear government human resources development with market awareness and promote common development between organizational environment and human resources.

4.3. Attention should be paid to the cultivation of new administrative cultures.

While Improving the administrative culture, some new administrative culture should be cultivated: open rather than not insular, compatible rather than exclusive, progressive rather than conservative, focusing more on efficiency than on form, more on the rules of law than on the rule of man, more on democracy than on authority.

4.4. Attention should be paid to the improvement of human resource development modes.

Construction of service-oriented government is an important objective in the reform of administrative system in China. The development modes of government human resources should be transformed from control-oriented to service-oriented so as to eventually develop a systemetic, circular, sustainable and professional mode for human resources. The administrative culture is the "soft environment" for government human resource development and systems and measures of human resource development are "hard environment" for government human resource development. Only by organicly combining the "soft environment" with "hard environment" can we promote the construction of the comprehensive development mode of government human resource.

\section{Implications and Conclusion}

In order to improve administrative culture and human resource development, departments should focus on here are the close relationship of mutual promotion and mutual restraint between the two, focusing on "win by culture", establishing good administrative values and beliefs, learning the advanced administrative ideas, following the scientific principles of administrative personnel, infusing "fresh blood" into administrative culture by good 
direction of public opinion and successful cases of human resources development which enable it to be imperceptibly influenced under an outstanding cultural environment so as to promote the comprehensive development of human resources.

\section{References}

[1]Tian Hua. On the administrative and cultural construction in minority areas and public administration reform[J]. Yunnan Nationalities University: Philosophy and Social Sciences,2002(2),28. (In Chinese)

[2]Our region will continue to maintain strong momentum in investigating cases of discipline violation[N]. Xinjiang Daily. 2009-05-07. (In Chinese)

[3]Chen Yushun. Undergraduate Teaching Evaluation formalism: the phenomenon, causes and countermeasures[J]. Fudan University Education Forum,2008(5),68. (In Chinese )

[4]William Fielding Ogburn, translation by Wang Xiaoyi, Chen Yuguo. Social change: the nature of cultural and congenital[M]. Zhejiang People's Publishing press,1989: 5. (In Chinese)

[5]Li Dezhi.Public sector human resource management and development. Beijing Science Press,2008: 76. (In Chinese) 